\title{
Konstruksi Makna Kandidat Politik Dalam Pemilu Kepala Daerah Bagi Masyarakat Kota Bandung (Perspektif Komunikasi Politik)
}

\author{
Evie Ariadne Shinta Dewi \\ Fakultas Ilmu Komunikasi, Universitas Padjadjaran, Bandung \\ evie@unpad.ac.id
}

\begin{abstract}
Bandung is the first city in Indonesia who respond to the decision of the Constitutional Court (MK), which allows candidates for district heads to be submitted individually not proposed by political parties and its implemented already in May 2008 elections. In the next period, candidates from individual lines are increasingly showing their enthusiasm, It can be seen in Bandung Mayor Elections in 2013 where four of the eight candidates who volunteered came from the individual path. The high enthusiasm of the Bandung community towards the nomination of regional heads from individual channels is an interesting phenomenon to be studied, especially from the voters's point of view.This study aims to investigate how Bandung people interpret and construct the meaning of perseorangant candidates and how they construct the comparison between perseorangant candidates and party representative candidates in the perspective of political communication. Method used in this study is phenomenological method by conducting indepth interview with 20 active voters from different occupation and education background in Bandung. The result indicates that informants interpret the existence of perseorangant candidates as the manifestation of genuine democracy, which based on the equality of rights and obligations of Indonesian people wherein civil people are able and allowed to nominate themselves as the district leader without have to join a political party. Moreover, being a party representative or an perseorangant one is not the primary consideration for the informants in determining their choice during the election. Informants emphasize that the worthiness of a leader shown by his characters, track record, achievements, and his social approach, not merely a party representative or perseorangant one.
\end{abstract}

Keywords: independent candidates, municipal election, political communication

\begin{abstract}
Abstrak
Kota Bandung tercatat sebagai kota pertama di Indonesia yang pada Pemilu Walikota tahun 2008 mengimplementasikan hasil keputusan Mahkamah Konstitusi (MK) yang membolehkan calon kepala daerah diajukan secara perseorangan (bukan diajukan oleh partai politik). Pada periode berikutnya, calon dari jalur perseorangan makin menunjukkan antusiasmenya, hal ini terlihat pada Pemilu Walikota Bandung tahun 2013 dimana empat dari delapan calon yang mengajukan diri berasal dari jalur perseorangan. Antusiasme masyarakat kota Bandung yang tinggi terhadap pencalonan kepala daerah dari jalur perseorangan merupakan fenomena yang menarik untuk dikaji, khususnya dari sudut pandang pemilih. Penelitian ini bertujuan untuk mengkaji bagaimana masyarakat mengkonstruksi makna calon dari jalur perseorangan dan calon dari partai politik dengan menggunakan perspektif komunikasi politik. Penelitian ini menerapkan metode fenomenologi dengan melakukan wawancara mendalam terhadap 10 pemilih aktif di kota
\end{abstract}


Bandung dari berbagai latar belakang pekerjaan dan pendidikan. Hasil penelitian menunjukkan bahwa informan memaknai keberadaan calon dari jalur perseorangan sebagai bentuk perwujudan demokrasi yang berlandaskan pada prinsip kesamaan hak dan kewajiban bagi seluruh rakyat Indonesia, dimana seseorang bisa mencalonkan dirinya sebagai calon kepala daerah tanpa harus menjadi bagian atau kader dari partai politik tertentu. Selain itu, informan juga memaknai pencalonan dari jalur perseorangan maupun dari jalur partai bukanlah faktor yang signifikan bagi mereka dalam menentukan pilihan. Informan memandang bahwa faktor utama penentu layak atau tidaknya seseorang dipilih menjadi kepala daerah adalah karakter, prestasi dan pendekatannya terhadap masyarakat, bukan dari soal dari jalur pencalonan mana dia berasal.

Kata Kunci: calon perseorangan, komunikasi politik, pemilu kepala daerah

\section{Pendahuluan}

Eksistensi calon perseorangan dalam pemilihan umum kepala daerah (selanjutnya disebut dengan Pemilukada) sepenuhnya diatur dan dijamin keabsahannya dalam perundang-undangan yaitu pasal 41 \& 42 UU Nomor 10 Tahun 2016 tentang "Perubahan Kedua Atas Undang-Undang

Nomor 1 Tahun 2015 Tentang Penetapan Peraturan Pemerintah Pengganti Undang-Undang Nomor 1 Tahun 2014 Tentang Pemilihan Gubernur, Bupati, Dan Walikota Menjadi Undang-Undang", yang menyatakan bahwa pasangan calon kepala dan wakil kepala daerah dapat diajukan secara perseorangan apabila mereka dapat membuktikan dukungan berupa surat dukungan berupa fotokopi kartu tanda penduduk (KTP) sebanyak 6,5 hingga 10 persen dari total jumlah Daftar Pemilih Tetap (DPT). Kehadiran calon perseorangan dalam Pemilukada ini dimungkinkan sejak Mahkamah Konstitusi (MK) meloloskan uji materil UU Nomor 32 Tahun 2004 tentang Pemerintah Daerah (Pemda) di Jakarta pada Juli 2007. Putusan MK ini selanjutnya diatur secara lebih jelas dan terperinci dalam UU No.12 Tahun 2008 tentang Perubahan Kedua atas UU Republik Indonesia No.32 Tahun 2004 tentang Pemerintahan Daerah dan disempurnakan dalam UU no 1 tahun 2015.

Pemilukada sendiri merupakan sebuah proses demokrasi yang sudah berlangsung sejak tahun 2005 dengan menggunakan prinsip one man one vote one value, artinya nilai suara setiap pemilih dihargai secara sama, satu orang, satu suara, satu nilai. Prinsip ini membawa perubahan yang cukup berarti bagi demokrasi Indonesia, mengingat dalam pemilihan kepala daerah masa sebelumnya kepala daerah dipilih secara tertutup oleh Dewan Perwakilan Rakyat Daerah (DPRD) sehingga rakyat tidak dilibatkan secara langsung. Dalam hasil studinya, Saraswati (2011) menyebutkan bahwa mekanisme rekrutmen atau mekanisme pengisian jabatan kepala daerah dan wakil kepala daerah merupakan perjalanan politik panjang, yang dituangkannya dalam matriks perbandingan mekanisme pengisian jabatan kepala daerah sebagai berikut: 
Evie Ariadne Shinta Dewi : Konstruksi Makna Kandidat Politik Dalam Pemilu Kepala Daerah Bagi Masyarakat Kota Bandung (Perspektif Komunikasi Politik)

Tabel 1. Perbandingan Mekanisme Pengisian Jabatan Kepala I Daerah

\begin{tabular}{|c|c|c|c|c|}
\hline No & $\begin{array}{l}\text { Peraturan perundang- } \\
\text { undangan }\end{array}$ & Sumber calon & $\begin{array}{l}\text { Kepala daerah } \\
\text { provinsi }\end{array}$ & $\begin{array}{l}\text { Kepala daerah } \\
\text { kabJKota }\end{array}$ \\
\hline 1 & UU No.1/1945 & $\begin{array}{l}\text { Dari Badan } \\
\text { Perwakilan } \\
\text { Rakyat Derah }\end{array}$ & $\begin{array}{l}\text { Diangkat oleh } \\
\text { Presiden }\end{array}$ & $\begin{array}{l}\text { Diangkat oleh } \\
\text { Mendagri }\end{array}$ \\
\hline 2 & UU No.22/1948 & $\begin{array}{l}\text { Dari anggota } \\
\text { DPRD }\end{array}$ & $\begin{array}{l}\text { Diangkat oleh } \\
\text { Presiden }\end{array}$ & $\begin{array}{l}\text { Diangkat oleh } \\
\text { Mendagri }\end{array}$ \\
\hline 3 & UU No.1/1957 & $\begin{array}{l}\text { Dari anggota } \\
\text { DPRD }\end{array}$ & $\begin{array}{l}\text { Kepala daerah } \\
\text { dipilih dari } \\
\text { anggota DPRD } \\
\text { diangkat oleh } \\
\text { Presiden }\end{array}$ & $\begin{array}{l}\text { Kepala daerah } \\
\text { dipilih dari } \\
\text { anggota DPRD. } \\
\text { Diangkat oleh } \\
\text { Mendagri }\end{array}$ \\
\hline 4 & Penpres No. 6/1959 & $\begin{array}{l}\text { Dari birokrat dan } \\
\text { ABRI yang } \\
\text { mendapat } \\
\text { dukungan parpol }\end{array}$ & $\begin{array}{l}\text { Diajukan oleh } \\
\text { DPRD. Diangkat } \\
\text { oleh Presiden }\end{array}$ & $\begin{array}{l}\text { Diajukan oleh } \\
\text { DPRD. } \\
\text { Diangkat oleh } \\
\text { Mendagri } \\
\text { dengan } \\
\text { persetujuan } \\
\text { Presiden }\end{array}$ \\
\hline 5 & UU No.18/1965 & $\begin{array}{l}\text { Dari birokrat dan } \\
\text { ABRI yang } \\
\text { mendapat } \\
\text { dukungan parpol }\end{array}$ & $\begin{array}{l}\text { Diangkat dan } \\
\text { diberhentikan } \\
\text { oleh Presiden, } \\
\text { calon diajukan } \\
\text { oleh DPRD }\end{array}$ & $\begin{array}{l}\text { Diangkat dan } \\
\text { diberhentikan } \\
\text { oleh Mendagri } \\
\text { dengan } \\
\text { persetujuan } \\
\text { Presiden, calon } \\
\text { diajukan oleh } \\
\text { DPRD }\end{array}$ \\
\hline 6 & UU No.5/1974 & $\begin{array}{l}\text { Dari birokrat dan } \\
\text { ABRI yang } \\
\text { mendapat } \\
\text { dukungan parpol }\end{array}$ & $\begin{array}{l}\text { Dicalonkan dan } \\
\text { dipilih DPRD } \\
\text { (3orang) yang } \\
\text { telah disepakati } \\
\text { bersama dengan } \\
\text { Mendagri }\end{array}$ & $\begin{array}{l}\text { Dicalonkan dan } \\
\text { dipilih DPRD } \\
\text { (3orang) yang } \\
\text { telah disepakati } \\
\text { bersama } \\
\text { dengan } \\
\text { Guberenur }\end{array}$ \\
\hline 7 & UU No.22/1999 & Partai Politik & $\begin{array}{l}\text { Dipilih oleh } \\
\text { DPRD }\end{array}$ & $\begin{array}{l}\text { Dipilih oleh } \\
\text { DPRD }\end{array}$ \\
\hline 8 & UU No.32/2004 & Partai Politik & $\begin{array}{l}\text { Dipilih oleh } \\
\text { rakyat }\end{array}$ & $\begin{array}{l}\text { Dipilih oleh } \\
\text { rakyat }\end{array}$ \\
\hline 9 & UU No.12/2008 & $\begin{array}{l}\text { Partai Politik dan } \\
\text { perseorangan }\end{array}$ & $\begin{array}{l}\text { Dipilih oleh } \\
\text { rakyat }\end{array}$ & $\begin{array}{l}\text { Dipilih oleh } \\
\text { rakyat }\end{array}$ \\
\hline
\end{tabular}

(Sumber: Saraswati, 2011)

Memiliki sejarah panjang mekanisme pemilihan kepala daerah sejak Indonesia merdeka, pemilihan kepala daerah secara langsung yang berlaku saat ini dianggap sebagai terobosan besar, tidak hanya dari aspek legal konstitusional, tapi juga dalam aspek pendidikan demokrasi bagi masyarakat. dalam konteks calon perseorangan, aspek HAM dan hak politik warga negara yaitu berhak memilih dan 
dipilih menemukan keniscayaan, meskipun persyaratan yang diajukan oleh undang-undang untuk calon perseorangan tidaklah mudah, namun hal ini membuktikan bahwa sistem hukum di negara ini telah menjunjung tinggi hak-hak individunya melalui jalur demokrasi yang nyata.

Warjiyati (2014) menyatakan bahwa pengaturan hukum mengenai pemilihan umum kepala daerah memperlihatkan perkembangan dan dinamika yang positif bagi perwujudan kehidupan demokrasi di Indonesia, dengan membuka ruang politis dan hukum bagi kesempatan calon perseorangan, selain calon yang diusung partai politik, untuk mengikuti pemilihan kepala daerah baik di tingkat provinsi, kabupaten, maupun kota. Dengan adanya kebijakan pengajuan calon dari jalur perseorangan, masyarakat memiliki alternatif pilihan dalam memilih pemimpin daerah jika calon yang disodorkan partai politik kurang memenuhi aspirasi masyarakat.

Di sisi lain, partai politik dalam melaksanakan fungsi-fungsinya senantiasa mempertimbangkan kelompok-kelompok yang ada di dalamnya dan tujuan-tujuan yang hendak dicapainya (Kadir, 2014). Kepentingan dan tujuan kelompok atau dikenal dengan istilah faksi inilah yang senantiasa didahulukan oleh para pemimpin pemenang pemilu yang diusung oleh partai. Kecenderungan tersebut sudah menjadi rahasia umum dan dipahami baik oleh masyarakat awam. Hal ini jugalah yang merupakan salah satu faktor penyebab calon pemimpin yang disodorkan oleh partai politik dirasa kurang memenuhi aspirasi masyarakat.

Munculnya calon perseorangan dalam Pemilukada merupakan perubahan besar dalam sistem demokrasi Indonesia. Selayaknya setiap perubahan, munculnya calon perseorangan dalam Pemilukada pun menuai pro dan kontra. Pro dan kontra tidak hanya datang dari kalangan politisi, pengamat dan aktor politik lainnya melainkan juga dari kalangan masyarakat awam. Kinerja partai politik yang dinilai negatif, khususunya berkaitan dengan banyaknya kasus korupsi yang menimpa para pemimpin partai politik, menimbulkan ketidakpercayaan dan apatisme dalam diri masyarakat awam. Hal ini turut mempengaruhi sikap masyarakat terhadap calon pemimpin yang diusung oleh partai politik yang berujung pada menurunnya minat masyarakat terhadap proses Pemilukada. Timbul prasangka dan praduga di kalangan masyarakat awam tentang kinerja para calon pemimpin usungan partai politik ini. Ada kecenderungan distrust yang tinggi terhadap partai politik, khususnya terhadap calon yang diusungnya. Pada titik ini, kemunculan calon perseorangan dianggap membawa pilihan lain atas krisis kepercayaan masyarakat terhadap partai politik. Kemunculan calon perseorangan, meskipun tidak sepenuhnya merupakan jalan keluar dari dilema krisis kepercayaan terhadap partai politik yang dihadapi oleh masyarakat, namun cukup untuk mengembalikan minat masyarakat terhadap proses Pemilukada yang berlangsung.

Masyarakat kota Bandung menunjukkan antusiasme yang besar terhadap proses Pemilukada pada dua kali proses Pemilukada terakhir, yakni pada tahun 2008 dan 2013. Hal ini ditunjukkan oleh meningkatnya keikutsertaan calon perseorangan pada dua proses Pemilukada tersebut. Bahkan pada tahun 2013, tercatat terdapat empat calon perseorangan yang mengajukan diri dari delapan calon yang maju untuk memperebutkan posisi Walikota Bandung. Meningkatnya 
minat pencalonan melalui jalur perseorangan dalam Pemilukada di kota Bandung yang cukup besar kemudian menimbulkan pertanyaan, apakah calon perseorangan memang memiliki peluang yang cukup besar di kota Bandung? Pertanyaan tersebut hanya bisa dijawab oleh para pemilih yakni masyarakat kota Bandung sendiri. Artikel ini bertujuan untuk mengkaji bagaimana masyarakat pemilih kota Bandung memaknai calon perseorangan dan calon dari partai politik dalam Pemilukada. Pada bagian pertama, artikel ini akan menyajikan konstruksi makna masyarakat pemilih kota Bandung terhadap calon perseorangan dan calon perwakilan partai. Selanjutnya pada bagian kedua artikel ini akan membahas tentang bagaimana konstruksi makna yang dibangun oleh masyarakat pemilih kota Bandung dalam membandingkan calon perseorangan dengan calon perwakilan partai dari perspektif komunikasi politik. Lebih spesifik lagi dengan menggunakan teori fenomenologi sebagai landasan teoretik memahami konstruksi makna para informan tetang kandidat politik dalam pemilukada.

\section{Metode Penelitian}

Untuk mencapai tujuan penelitian tentang konstruksi makna calon perseorangan dan calon dari partai politik, penelitian ini menggunakan pendekatan fenomenologi. Istilah phenomenon mengacu pada sebuah benda, kejadian, atau kondisi yang dilihat. Oleh karena itu, fenomenologi merupakan cara yang digunakan manusia untuk memahami pengalaman nyata sebagai data pokok sebuah realitas yang kemudian berupaya untuk mengungkap bagaimana anggota masyarakat menggambarkan dunia sehari-harinya terutama bagaimana individu dengan kesadarannya membangun makna dari hasil interaksinya dengan individu lainnya (Ardianto, 2011).

Alfred Schutz, yang pertama kali memperkenalkan fenomenologi dalam ilmu sosial, berpendapat bahwa pengalaman dan perilaku manusia dalam dunia sosial keseharian sebagai realitas yang bermakna secara sosial. Fenomenologi menurut Schutz menempatkan komunikasi sebagai faktor penting bagi realitas yang dialami seseorang. Realitas bagi kita bergantung pada apa yang kita pelajari dari orang lain dalam komunitas sosial budaya kita, yang terbentuk dalam suatu situasi historis. Pengertian dan pemahaman kita pada dasarnya timbul dari komunikasi kita dengan orang lain.

Pengetahuan manusia adalah konstruksi yang dibangun dari proses kognitif dengan interaksinya terhadap dunia objek material dan pengalaman manusia terdiri dari interpretasi bermakna terhadap kenyataan dan bukan reproduksi kenyataan. Dengan demikian, makna yang dibangun masyarakat pemilih kota Bandung terhadap calon perseorangan dan calon partai politik dalam Pemilukada merupakan hasil dari pengalaman yang terorganisir dan bermakna.

Menurut Kuswarno (2009:61), ada beberapa kriteria umum dalam memilih informan dalam penelitian fenomenologi: informan adalah mereka yang mengalami langsung situasi atau kejadian yang kaitan dengan topik penelitian. Informan juga dinilai mampu menggambarkan kembali fenomena yang telah dialaminya. Selain itu, informan harus bersedia untuk terlibat dalam kegiatan penelitian dan bersedia untuk diwawancarai dan direkam aktivitasnya selama 
wawancara. Subjek dalam penelitian ini adalah individu anggota masyarakat kota Bandung yang aktif mengikuti Pemilukada. Oleh karena tingkat keragaman karakteristik masyarakat kota Bandung yang tinggi, maka teknik yang digunakan dalam penentuan informan ini adalah purposive sampling, yakni pengambilan sampel sumber data dengan pertimbangan tertentu.

Peneliti menentukan beberapa kriteria dalam penentuan informan, yakni: masyarakat biasa yang sudah menjadi pemilih aktif pada kegiatan pemilu maupun pemilukada. Berdasarkan kriteria tersebut secara purposive diperoleh 10 informan, yakni: MS (50thn, PNS), AN (38thn, Wiraswasta), NA (49thn, Wiraswasta), WP (38thn, Pegawai swasta), LS (55thn, Wiraswasta), H (59thn, Pensiunan PNS), E (59thn, Wiraswasta), F (33thn, Wiraswasta), C (23thn, Ibu Rumah Tanga), dan Y (25thn, Ibu Rumah Tangga). Semua informan terdaftar sebagai pemilih dalam Pilwalkot Bandung tahun 2013 dan aktif memberikan suaranya. Sedangkan objek penelitian ini adalah konstruksi makna calon perseorangan dan calon perwakilan partai dari perspektif komunikasi politik.

Data diperoleh dengan melakukan wawancara mendalam kepada para informan yang sudah ditentukan kriterianya, pengamatan dalam kegiatan pemilukada kota Bandung serta studi dokumentasi.

Untuk keabsahan data, peneliti melakukan triangulasi sumber dengan cara mengkonfirmasi kembali interpretasi peneliti kepada para informan atas data yang diperoleh saat wawancara. Selain itu triangulasi juga dilakukan terhadap beberapa kandidat yang terlibat dalam pemilukada.

\section{Hasil Penemuan dan Diskusi}

Calon perseorangan dalam Pemilukada sejak tahun 2005 merupakan sebuah fenomena baru bagi demokrasi Indonesia. Banyaknya partai politik peserta pemilu maka semakin banyak pula calon pemimpin yang berasal dari partai politik. Pemberlakuan UU No.32 tahun 2004 tentang Pemerintahan Daerah yang memungkinkan rakyat biasa - bukan kader dan anggota partai politik untuk mencalonkan dirinya sendiri sebagai calon pemimpin tanpa harus diusung partai kemudian mereformasi peta pertarungan politik pada ajang Pemilukada.

Hadirnya calon perseorangan dalam Pemilukada sendiri menuai pendapat yang beragam dari masyarakat pemilih. Masyarakat pemilih kota Bandung telah merasakan proses Pemilukada yang diikuti oleh calon perseorangan selama dua periode, yakni pada tahun 2008 dan tahun 2013.

Dari kegiatan wawancara yang dilakukan, rata-rata informan menyatakan setuju dengan adanya calon dari jalur non partai sebagai penyeimbang jika calon dari partai politik dianggap tidak cukup memenuhi ekspektasi mereka. Selain itu, menurut informan calon perseorangan merupakan representasi pelaksanaan demokrasi yang sesungguhnya, karena sesuai dengan makna demokrasi itu sendiri, yakni dari rakyat, oleh rakyat, dan untuk rakyat. Menurut informan, kehadiran calon perseorangan merupakan hakikat dari rakyat, oleh rakyat, dan untuk rakyat. Hal tersebut menunjukkan konstruksi makna yang informan bangun terhadap calon perseorangan dari sudut pandang sistem demokrasi itu sendiri. 
Temuan lain memperlihatkan bahwa dari sudut pandang kecenderungan memilih, terdapat beragam makna yang dikonstruksi oleh informan berdasarkan pengalamannya mengikuti Pemilukada dengan calon baik dari perwakilan partai maupun jalur perseorangan. Beberapa informan menolak calon perseorangan dan lebih memilih calon perwakilan partai politik karena adanya kekhawatiran tentang tidak jelasnya rekap jejak kiprah politik calon perseorangan. Ketidakjelasan rekam jejak kiprah politik membuat informan risau akan kinerja yang akan dihasilkan oleh calon perseorangan ke depannya ketika memenangi pemilu. Informan Y, seorang ibu rumah tangga, menyampaikan pendapatnya sebagai berikut:

"Ya kalau bisa mah dari partai.... kan kita kan tahu ya, oh, dia dari partai ini, jadi jelas latar belakang partainya... Tapi kalau dia dari yang, apa namanya, kayak si Ahok itu, itu kan kita nggak tahu ya latar belakang politiknya, ya istilahnya nggak resmi gitu...."

Selain menyangsikan rekam jejak kiprah politik calon perseorangan, informan juga memaknai proses dibalik pencalonan itu sendiri. Proses candidacy calon perseorangan yang dilegitimasi dengan pengumpulan KTP masyarakat pendukung berdasarkan ketentuan perundang-undangan memunculkan kekhawatiran lainnya. Informan menyangsikan kejujuran, kebersihan, dan kevalidan proses pengumpulan KTP tersebut. Beberapa informan sangsi bahwa kegiatan pengumpulan KTP tersebut didapatkan atas dasar kerelaan masyarakat untuk ikut mengumpulkannya. Informan beranggapan bahwa selalu ada kemungkinan KTP yang dikumpulkan bukan murni atas keinginan masyarakat pemilih, melainkan dilakukan atas tanpa sepengetahuannya. Hal ini mengingat banyak kegiatan pendaftaran dan penukaran kupon di tempat-tempat perbelanjaan yang membutuhkan fotocopy KTP masyarakat, sehingga ada kecurigaan mungkin saja KTP yang dikumpulkan oleh para pendukung calon perseorangan didapatkan dari sumber-sumber demikian, dan bukan dari masyarakat pemilih itu sendiri. Seorang informan, MS (PNS), memaparkan pendapatnya:

"Ya kalau memang dia murni perseorangan dan didukung oleh masyarakat tidak jadi masalah. Tapi asal jangan istilahnya, kan yang banyak salah kaprah itu kan tim suksesnya, apakah calonnya itu mengumpulkan sendiri fotocopy KTP? kan enggak. Kalau tim sukses kan dia, misalnya dijanjikan 1 KTP sekian, kan dengan sendirinya bisa diusahakan, misalnya ketika pengurusan administrasi segala macam kan menggunakan fotocopy KTP, itu kan bisa dimanfaatkan. Begitu dia bisa digunakan untuk kepentingan pemilukada, sebagai pendukung perseorangan. Coba perhatikan, hasil pengumpulan fotocopy KTP, dicrosscheck aja, ambil sampelnya, apakah benar dia mendukung orang tersebut? Belum tentu. Hal ini masih riskan kecurangan. Karena belum tentu caranya benar."

Di sisi lain, ada sekelompok informan yang masih berpikiran positif terhadap pengajuan calon perseorangan, bahwa sebetulnya hal tersebut sah-sah saja dan wajar. Kelompok informan ini berprinsip bahwa terlepas dari calon pemimpin yang akan mereka pilih dari partai politik ataupun dari jalur 
perseorangan, yang menjadi pertimbangan utama mereka dalam memilih adalah figur calon itu sendiri, rekam jejak kiprah politik dan kinerjanya, serta citranya di mata masyarakat. Kelompok informan ini memandang bahwa kapasitas pribadi calon pemimpinlah yang menentukan dia dipilih atau tidak, bukan latar belakang pencalonannya. Berikut tanggapan beberapa informan terkait hal tersebut:

"Kalau menurut saya, ya mungkin susah juga ya kayaknya, tapi kalau memang tidak masuk partai tapi dia banyak pendukungnya, kalau memang dia hasil kerjanya bagus juga nggak apa-apa mungkin, bisa juga ya...." (E, 58 tahun, wiraswasta)

"Kalau memang kualitasnya bagus, ke masyarakatnya bagus, kan masyarakat membutuhkan...., bukan pilih partai, masyarakat memilih orang tersebut yang dijadikan pemimpin itu yang bagus ke masyarakat, yang berguna untuk masyarakat, mau dari kalangan apapun ya silahkan saja, gitu...." (LS, 55 tahun, wiraswasta)

Kendati positif, informan juga memiliki kekhawatiran lain jika calon perseorangan tersebut memenangi Pemilukada. Informan berpandangan seorang calon perseorangan sebagai kepala daerah akan menghadapi krisis besar dalam upaya untuk menjalankan dan mengimplementasikan program-program yang dimilikinya untuk daerah karena tidak adanya dukungan di kursi pemerintahan yang dikuasai oleh perwakilan-perwakilan partai politik. Informan menyangsikan kemajuan dan perubahan yang bisa dilakukan oleh calon perseorangan untuk daerahnya dengan tidak adanya dukungan partai politik di pemerintahan.

Secara sederhana, konstruksi makna informan terhadap calon perseorangan dan calon perwakilan partai politik dalam Pemilukada peneliti rangkum dalam gambar berikut:

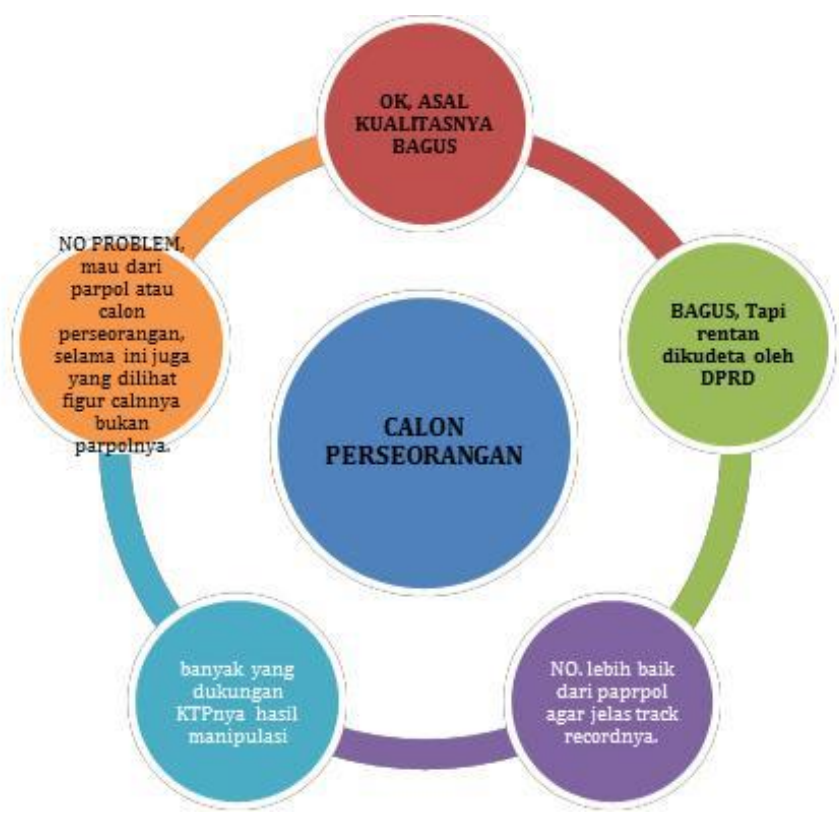

Gambar 1: Konstruksi Makna Calon Perseorangan (Sumber: Peneliti) 
Gambar di atas memberikan gambaran bagaimana informan memaknai calon perseorangan dan calon dari partai politik dalam Pemilukada kota Bandung. Meskipun terdapat pemaknaan yang berbeda-beda, namun seluruh informan tidak keberatan dengan kehadiran calon perseorangan dalam Pemilukada kota Bandung. Selain itu, enam dari sepuluh informan mendasarkan pilihan kepala daerahnya pada pertimbangan figur personal calon pemimpin itu sendiri, bukan latar belakang pencalonannya. Semua informan memandang bahwa calon perseorangan selayaknya harus memperoleh dukungan secara jujur dan bersih dari masyarakat, bukan dengan praktek curang seperti manipulasi dukungan KTP. Karena jika hal tersebut tidak dapat dilakukan maka calon perwakilan partai dianggap lebih baik karena memiliki keunggulan dari segi rekam jejak kiprah politik yang dapat dilacak kembali ke partainya masing-masing.

Secara historis, munculnya calon perseorangan memang diawali dengan menurunnya tingkat kepercayaan masyarakat terhadap partai politik yang begitu signifikan akibat ketidakmampuan partai politik mengusung kader-kader yang berkualitas dalam proses Pemilukada di manapun. Puncak ketidakpercayaan masyarakat terhadap partai politik ini kemudian seolah-olah dilegitimasi oleh keputusan Mahkamah Konstitusi (MK) yang memungkinkan calon kepala daerah tidak harus berasal dari partai politik, tapi juga dari jalur perseorangan.

Adanya kebijakan baru ini memberikan alternatif kepada masyarakat dalam memilih pemimpin daerahnya. Selain itu, individu-individu yang merasa memiliki kemampuan untuk mencalonkan diri sebagai kepala daerah namun bukan anggota ataupun kader partai politik, dapat menggunakan haknya untuk dipilih sebagai pemimpin melalui jalur perseorangan. Dengan kata lain, keputusan MK tentang calon perseorangan seakan memberi jalan lain bagi kebuntuan politik akibat minimnya kepercayaan masyarakat terhadap partai politik beberapa tahun belakangan ini.

Informan membangun konstruksi makna terhadap dua jenis calon pemimpin - calon perseorangan dan calon perwakilan partai - berdasarkan pengalaman yang mereka rasakan dari setiap pemilu yang diikuti, khususnya Pemilukada. Pengalaman sadar dan pengetahuan yang informan miliki sehubungan dengan pemimpin-pemimpin daerah yang sebelumnya kemudian menghasilkan pemaknaan yang berbeda-beda terkait dengan fenomena calon pemimpin dari jalur perseorangan dan perwakilan partai. Pemaknaan yang informan berikan dapat dijadikan referensi tentang bagaimana masyarakat pemilih kota Bandung memandang dan menilai kiprah calon perseorangan baik sebagai calon pemimpin maupun jika terpilih sebagai pemimpin. Sebagai masyarakat awam, makna yang dikonstruksi oleh informan dapat dikatakan bebas nilai dan keberpihakan karena tidak adanya tendensi politik di dalamnya.

Menilik pemaknaan informan yang seluruhnya pro terhadap kehadiran calon perseorangan dalam Pemilukada, hal ini kemudian relevan dengan tingginya antusiasme masyarakat untuk mencalonkan dirinya sebagai calon dalam Pemilukada tahun 2013 lalu. Meskipun sebagian besar informan lebih mempertimbangkan kualitas personal individu calon pemimpin alih-alih latar belakang jalur pencalonannya, tidak berarti calon perseorangan memiliki kesempatan yang sama besar dengan calon perwakilan partai. Karena kualitas 
personal individu calon pemimpin yang menjadi pertimbangan utama para informan adalah karakter, rekam jejak kiprah politik, prestasi, dan pendekatannya terhadap masyarakat.

Jika merujuk pada konsep, bahwa konstruksi makna adalah sebuah proses dimana individu mengelola dan menginterpretasikan kesan-kesan sensor yang mereka terima untuk memberikan makna bagi lingkungannya, maka para informan melalui penalamannya sebagai pemilih dalam pemilukada kota Bandung menginterpretasikan kesan sensor atas kandidat politik yang mereka pilih. Konstruksi makna yang terbentuk untuk calon perseorangan maupun calon dari partai politik, bagi informan diinterpretasikan sebagai individu yang harus memenuhi kriteria yang sesuai dengan nilai-nilai yang mereka anut, seperti dikemukakan pada bagian paparan data di atas yakni: jujur, punya jiwa kepemimpinan, cerdas, tidak korupsi, memiliki karakter, rekam jejak politik yang jelas dan positif, berprestasi, dan memiliki modal social di masyarakat. Konstruksi makna seperti ini terbentuk karena pembentukan makna dapat dikatakan sebagai sebuah proses berfikir, dan para informan memiliki kemampuan berfikir sesuai dengan kemampuan kognitifnya, maka mereka memkonstruksi makna sesuai dengan muatan informasi yang mereka terima tentang para kandidat politik tersebut.

\section{Simpulan}

Adanya kebijakan baru tentang calon perseorangan memberikan alternatif kepada masyarakat dalam memilih pemimpin daerahnya. Selain itu, individuindividu yang merasa memiliki kemampuan untuk mencalonkan diri sebagai kepala daerah namun bukan anggota ataupun kader partai politik, dapat menggunakan haknya untuk dipilih sebagai pemimpin melalui jalur perseorangan. Dengan kata lain, keputusan MK tentang calon perseorangan seakan memberi jalan lain bagi kebuntuan politik akibat minimnya kepercayaan masyarakat terhadap partai politik beberapa tahun belakangan ini.

Di sisi lain, informan memaknai keberadaan calon dari jalur perseorangan sebagai bentuk perwujudan demokrasi yang berlandaskan pada prinsip kesamaan hak dan kewajiban bagi seluruh rakyat Indonesia, dimana seseorang bisa mencalonkan dirinya sebagai calon kepala daerah tanpa harus menjadi bagian atau kader dari partai politik tertentu. Selain itu, informan juga memaknai pencalonan dari jalur perseorangan ataupun dari jalur partai bukanlah faktor yang signifikan bagi mereka dalam menentukan pilihan. Informan memandang bahwa faktor utama penentu layak atau tidaknya seseorang dipilih menjadi kepala daerah atau pemimpin adalah karakter, rekam jejak kiprah politik, prestasi, dan pendekatannya terhadap masyarakat.

\section{Ucapan Terima Kasih}

Artikel ini dibuat berdasarkan hasil penelitian mandiri yang dilakukan bersama dengan para asisten dosen mata kuliah Komunikasi Politik, untuk itu penulis menyampaikan terimakasih kepada dua orang dosen muda Fakultas Ilmu 
Komunikasi Universitas Padjadjaran, Benazir Bona Pratama, S.Sos, M.Si dan Putri Limilia, S.Sos, M.Si. selain itu ucapan terimakasih juga disampaikan untuk redaksi Jurnal Komunikasi Universitas Tarumanagara yang berkenan memuat artikel ini.

\section{Daftar Pustaka}

Ardianto, MSi, D. (2011). Metodologi Penelitian untuk Public Relations Kuantitatif dan Kualitatif. Bandung: PT.Remaja Rosdakarya.

Kadir, A. Gau. (2014). Dinamika Partai Politik di Indonesia. Sosiohumaniora, Vol. 16 No.2, Juli 2014, 132-136.

Kuswarno, Engkus, Prof., Dr., M.S. (2009). Fenomenologi Metodologi Penelitian Komunikasi Konsepsi, Pedoman, dan Contoh Penelitian. Bandung: Widya Padjadjaran.

Saraswati, Retno. (2011). Calon Perseorangan: Pergeseran Paradigma Kekuasaan dalam Pemilukada. MMH, Jilid 40 No.24 April 2011, 196-201.

Warjiyati, Sri. (2014). Calon Perseorangan dalam Pemilihan Umum Kepala Daerah. Al-Daulah, Vol.4 No.1 April 2014, 112-135. 